\title{
GROWTH DYNAMICS OF SESAME CULTIVARS ${ }^{1}$
}

\author{
RAYANNE MARIA PAULA RIBEIRO ${ }^{2 *}$, JOSÉ RICARDO TAVARES DE ALBUQUERQUE ${ }^{2}$, MANOEL GALDINO \\ DOS SANTOS $^{2}$, AURÉLIO PAES BARROS JÚNIOR ${ }^{2}$, LEILSON COSTA GRANGEIRO², LINDOMAR MARIA DA \\ SILVEIRA $^{2}$
}

\begin{abstract}
Sesame is a plant with high morphological and physiological complexity, with great variability in growth habit. Quantitative growth analysis is an accessible and accurate tool for evaluating plant development and the contribution of different physiological processes to plant performance. In view of this, the purpose of this study was to evaluate the growth of sesame cultivars in two cropping seasons in the conditions of Mossoró-RN. Two experiments were conducted in Horta Didactics of UFERSA. The experimental delineation in each time was a randomized complete block design with four replications. The treatments were arranged in split plots where each experimental plot contained different sesame cultivars, CNPA G2, CNPA G3 and CNPA G4, and the subplots represented seven collection times, 21, 35, 49, 63, 77, 91 and 105 days after sowing (DAS). The growth of the sesame cultivars was slow at the beginning of the crop cycle, intensifying at the beginning of flowering (after 35 DAS). Among the physiological indexes studied, CNPA G4 cultivar was more efficient in relation to growth and varied depending on the cropping season.
\end{abstract}

Keywords: Sesamum indicum. Leaf area. Harvest time. Physiological parameters.

\section{DINÂMICA DO CRESCIMENTO DE CULTIVARES DE GERGELIM}

RESUMO - O gergelim é uma cultura de elevada complexidade morfofisiológica, com grande variabilidade no hábito de crescimento. A análise quantitativa do crescimento é uma ferramenta acessível e precisa para avaliar o desenvolvimento vegetal e a contribuição de diferentes processos fisiológicos sobre o seu desempenho. Nesse sentido, objetivou-se avaliar o crescimento de cultivares de gergelim em duas épocas de cultivo nas condições de Mossoró-RN. Foram instalados dois experimentos na Horta Didática da UFERSA. O delineamento experimental em cada época foi em blocos casualizados completos, com quatro repetições. Os tratamentos foram dispostos em parcelas subdivididas, onde as parcelas foram representadas pelas cultivares de gergelim: CNPA G2, CNPA G3 e CNPA G4 e as subparcelas consistiram das épocas de coletas $(21 ; 35 ; 49 ; 63 ; 77 ; 91$ e 105 DAS). O crescimento das cultivares de gergelim é lento no início do ciclo vegetativo da cultura, se intensificando no início do florescimento (após os 35 DAS). Entre os índices fisiológicos estudados, a cultivar CNPA G4 apresenta ser mais eficiente em relação ao crescimento, podendo ser variado dependendo da época de cultivo.

Palavras-chave: Sesamum indicum. Área foliar. Época de coleta. Parâmetros fisiológicos.

\footnotetext{
${ }^{*}$ Corresponding author

${ }^{1}$ Received for publication in 09/19/2017; accepted in 03/08/2018.

Paper extracted from the master dissertation of the first author.

${ }^{2}$ Center for Agrarian Sciences, Universidade Federal Rural do Semi-Árido, Mossoró, RN, Brazil; rayanne tab@hotmail.com - ORCID: 0000-0001-8826-6142, ricardoalbuquerque2016@hotmail.com - ORCID: 0000-0003-4113-1501, manoel.galdino5@gmail.com - ORCID: 0000-0003-4972-5849, aurelio.barros@ufersa.edu.br - ORCID: 0000-0002-6983-8245, leilson@ufersa.edu.br - ORCID: 0000-0002-46133605, lindomarmaria@ufersa.edu.br-ORCID: 0000-0001-9719-7417.
} 


\section{INTRODUCTION}

Sesame (Sesamum indicum L.) is a plant species belonging to the family of pedaliáceas which originated in Africa. It is considered to be one of the oldest cultivated oleaginous plants in the world, previously recorded in $4300 \mathrm{BC}$, in countries such as Iran, Egypt, India and China (HARUNA et al., 2012; LIMA et al., 2013). The sesame crop has a high economic potential, due to possible exploration for national and international markets, arousing interest of small and large producers, due to its excellent nutritional properties. In addition, the seeds have an oil content of more than $50 \%$ with a high chemical stability, which is used in food and chemical industries and has potential for the production of energy via biodiesel (BEZERRA et al., 2010).

World production in 2014 was estimated at $5,469,024$ tons, with the main producing countries being India, China, and Sudan with outputs of $811,000,721,000$ and 632,108 tonnes, respectively. Brazil is considered to be a small producer, producing seven thousand tons in 2014 (FAO, 2016). The production of sesame in Brazil is mostly concentrated in grain cultivation areas in Goiás and some states in the Northeast. There are also areas of sesame production in São Paulo, Mato Grosso and Minas Gerais (ARRIEL et al., 2007).

The crop is adapted to various climatic conditions, is easy to grow and resistant to drought. The cultivars can be differentiated by several attributes, such as height, growth cycle, seed color, type of branching and resistance to pests and diseases. The seeds can be white, cream and black, with the first two having the highest commercial value (LAURETIN; BENÍTEZ, 2014; MORRIS, 2009). However, it is important to use cultivars adapted to the conditions of the growing regions to obtain higher productivity (PHAM et al., 2010).

Growth analysis is an essential tool in the study of the physiology of production and the investigation of the influence exerted by environmental, genetic and agronomic factors on plant productivity (ARAÚJO et al., 2014). Also, it provides practical knowledge and information regarding the growth and performance of the plants, making it possible to describe morphophysiological conditions at different time intervals, evaluated through physiological and biochemical indexes (PEIXOTO et al., 2012).

There are few studies involving the growth of cultivars in the Northeast Region of Brazil. The choice of cultivar for a given environment is of great importance for good productivity, where knowledge of the development of the varieties in different regions becomes fundamental to that decision. In this sense, the objective of this study was to evaluate the growth of sesame cultivars in two growing seasons in Mossoró-RN conditions.

\section{MATERIAL AND METHODS}

Experiments were conducted in the Department of Plant Sciences of the Universidade Federal Rural do Semi-Árido (UFERSA) in Mossoró -RN, Brazil ( $5^{\circ} 11^{\prime}$ latitude S, $37^{\circ} 20^{\prime}$ WG longitude and $18 \mathrm{~m}$ altitude), from November 2014 to February 2015 (season I) and from April to July 2015 (season II). The soil of the experimental area is classified as Eutrophic Yellow Red Argissolo (EMBRAPA, 2013). The chemical characteristics of the soil $(0-20 \mathrm{~cm}$ depth $)$ in season I were as follows: $\mathrm{pH}=7.90 ; \mathrm{CE}=0.17 \mathrm{dS} \mathrm{m}^{-1} ; \mathrm{N}=0.98 \mathrm{~g} \mathrm{~kg}^{-1}$; $\mathrm{MW}=14.11 \mathrm{~g} \mathrm{~kg}^{-1} ; \mathrm{K}=181.04 \mathrm{mg} \mathrm{dm}^{-3}$ $\mathrm{P}=197.09 \mathrm{mg} \mathrm{dm}^{-3} ; \mathrm{Na}=98.05 \mathrm{mg} \mathrm{dm}^{-3}$ $\mathrm{Ca}=4.88 \mathrm{cmolc} \mathrm{dm}^{-3}$; and $\mathrm{Mg}=0.37 \mathrm{cmolc} \mathrm{dm}^{-3}$. In season II, these were as follows: $\mathrm{pH}=7.75$; $\mathrm{CE}=0.09 \mathrm{dS} \mathrm{m} \mathrm{m}^{-1} ; \mathrm{N}=1.23 \mathrm{~g} \mathrm{~kg}^{-1}$; $\mathrm{MW}=15.60 \mathrm{~g} \mathrm{~kg}^{-1} ; \mathrm{K}=155.20 \mathrm{mg} \mathrm{dm}^{-3}$; $\mathrm{P}=201.95 \mathrm{mg} \mathrm{dm}^{-3} ; \mathrm{Na}=39.50 \mathrm{mg} \mathrm{dm}^{-3}$; $\mathrm{Ca}=5.22 \mathrm{cmolc} \mathrm{dm}^{-3}$; and $\mathrm{Mg}=1.55 \mathrm{cmolc} \mathrm{dm}^{-3}$.

During the conduct of the experiments, maximum and minimum temperatures and relative humidity were $35.50{ }^{\circ} \mathrm{C}, 23.27{ }^{\circ} \mathrm{C}$ and $62.47 \%$ (November 2014 to February 2015) and $34.78{ }^{\circ} \mathrm{C}$, $22.03{ }^{\circ} \mathrm{C}$ and $64.95 \%$ (April to July 2015), respectively.

The experimental design was a complete randomized complete block design, with four replications. The treatments were arranged in subdivided plots, where the cultivars (CNPA G2, CNPA G3, and CNPA G4) occupied the plots, and the collection times $(21,35,49,63,77,91$ and 105 days after sowing - DAS) the subplots. Each experimental unit consisted of four lines of $3.0 \mathrm{~m}$ length each, $2.4 \mathrm{~m}$ wide, considering as a useful area, the two central rows with 24 plants. The spacing used was $0.30 \times 0.60 \mathrm{~m}$, with two plants per well (population of 111,111 plants $\mathrm{ha}^{-1}$ ). For growth analysis, two competitive sesame plants from the useful area were sampled at each collection period at fourteen-day intervals up to 105 DAS and ten plants for yield evaluation.

Soil preparation consisted of plowing and harrowing. Application of fertilizer was based on the soil analysis and fertilizer recommendation for the sesame crop, according to Cavalcanti et al. (2008). In both experiments, fertilizer was applied as follows: $40 \mathrm{~kg} \mathrm{ha}^{-1}$ of $\mathrm{P}_{2} \mathrm{O}_{5}$ in the form of mono-ammonium phosphate and two coverages, $25 \mathrm{~kg}^{-1}$ of $\mathrm{N}$ at $10 \mathrm{DAS}$, and $25 \mathrm{~kg} \mathrm{ha}^{-1}$ of $\mathrm{N}$ and $20 \mathrm{~kg} \mathrm{ha}^{-1}$ of $\mathrm{K}_{2} \mathrm{O}$ in the form of urea and potassium sulfate at 20 DAS. The irrigation system used was by dripping, placing a hose in each row of plants, with drippers spaced $0.30 \mathrm{~m}$ apart and an average flow rate of $1.5 \mathrm{~L} \mathrm{~h}^{-1}$.

For growth analysis, regular plant collections were performed at 14-day intervals, the first taking place at 21 DAS. The following characteristics were evaluated: dry mass of the plant, obtained by drying in a forced air circulation oven at $65{ }^{\circ} \mathrm{C}$ until 
constant mass was achieved; leaf area, determined from the length $(\mathrm{C})$ and width (L) dimensions of all leaves, using a correction factor $\mathrm{f}(0.7)$ according to the equation $\mathrm{AF}=\mathrm{C} \times \mathrm{L} \times \mathrm{f}\left(\mathrm{cm}^{2}\right)$ (1) (SILVA et al., 2002); leaf area index: IAF $=\mathrm{AF} / \mathrm{AS}$ (2), where $\mathrm{AF}=$ leaf area $\left(\mathrm{cm}^{2}\right)$ and $\mathrm{AS}=$ soil area covered by the plant, in this case $60 \times 30 \mathrm{~cm}\left(\mathrm{~cm}^{2}\right)$ was considered available (PEIXOTO; CRUZ; PEIXOTO, 2011); leaf area ratio: $\mathrm{RAF}=\mathrm{AF} / \mathrm{W}\left(\mathrm{cm}^{2} \mathrm{~g}^{-1}\right)(3)$, where: $A F=$ leaf area $\left(\mathrm{cm}^{2}\right)$ and $\mathrm{W}=$ dry mass of the plant $(\mathrm{g})$; (W2-W1) / (T2-T1) $\left(\mathrm{g}^{\text {day }}{ }^{-1}\right)$ (4), where: $\mathrm{W} 2$ and $\mathrm{W} 1=$ plant dry mass of two consecutive samples $(\mathrm{g}), \mathrm{T} 2$ and $\mathrm{T} 1=(\mathrm{W} \times \mathrm{H})(\mathrm{g} \mathrm{cm}$ ${ }^{-2}$ day $^{-1}$ ) (5), where: $\mathrm{W}=$ dry mass of the plant $(\mathrm{g})$, $\mathrm{AS}=$ area of soil covered by the plant $\left(\mathrm{cm}^{2}\right)$ and time (days) and grain yield $\left(\mathrm{kg} \mathrm{ha}^{-1}\right)$, determined from the weight of the grains from the useful area, only the harvest was considered at the end of the cycle (105 DAS), the results being expressed in $\mathrm{kg}$ $\mathrm{ha}^{-1}$ (GRILO JUNIOR; AZEVEDO, 2013).

For each growing season, analysis of variance was performed on the evaluated characteristics using SISVAR 3.01 software (FERREIRA, 2011). A combined analysis was performed on the characteristic(s) with homogeneity of variance between the growing seasons. Adjustment of the response curves was carried out between the evaluated characteristics and the quantitative factors. Tukey's test $(p<0.05)$ was used to compare the means of the qualitative treatment.

\section{RESULTS AND DISCUSSION}
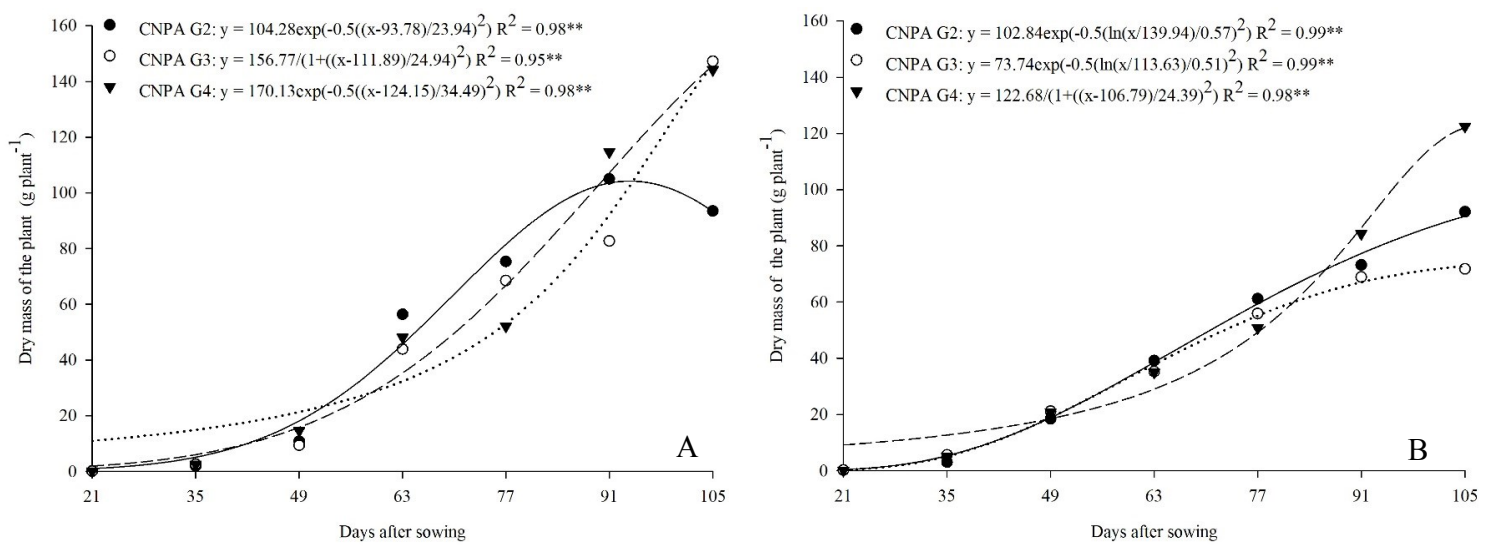

Figure 1. Dry mass of plants in relation to harvesting season of sesame cultivars in season I (A) and season II (B).

Leaf area growth was slow at the beginning of the crop cycle for all cultivars evaluated, intensifying from 35 DAS. In season I, the maximum maxima was $5129.46 \mathrm{~cm}^{2}$ (CNPA G2) at 88 DAS, 6044.71 $\mathrm{cm}^{2}$ (CNPA G3) at 85 DAS and $6601.00 \mathrm{~cm}^{2}$ (CNPA G4) at 95 DAS. In season II, values were $4207.29 \mathrm{~cm}^{2}$ (CNPA G2) obtained at 64 DAS; of $3457.34 \mathrm{~cm}^{2}$ (CNPA G3) at 60 DAS and 4068.98 $\mathrm{cm}^{2}$ (CNPA G4) at 76 DAS, then a decline was
The homogeneity of the variances was accepted for all the evaluated characteristics, allowing the accomplishment of the experiments analysis, occurring interaction between the cultivar, time of collection and cultivation for all the characteristics.

Accumulation of dry matter in the plant was slow up to 49 DAS and then intensified with all cultivars because the plants used much of the energy at the beginning of development for soil fixation, oncethe roots are the preferential drainage of photoassimilates (LUCENA et al., 2013). The maximum dry mass estimated in season I were 104.27 g plant $^{-1}$ (CNPA G2) at 93 DAS; and 145.66 (CNPA G3) and $145.81 \mathrm{~g} \mathrm{plant}^{-1}$ (CNPA G4), both at 105 DAS. In season II, the values were 90.46 (CNPA G2), 72.87 (CNPA G3) and 122.02 g plant $^{-1}$ (CNPA G4) at 105 DAS (Figure 1). According to Ferrari et al. (2008), the accumulation of phytomass increases the demand for photoassimilates to maintain existing structures, thus reducing the amount of assimilates available for plant growth and favoring the reproductive phase at the end of the cycle.

With regard to the cultivars, in season I there was a significant difference between cultivars from 49 DAS, with CNPA G3 and CNPA G4 having greater dry mass at 105 DAS. In season II, there was a significant difference between cultivars from 77 DAS; CNPA G4 was superior to the other cultivars, with a maximum accumulation of dry mass at 105 DAS. observed (Figure 2). Consistent with the results of Silva et al. (2014) when studying sesame genotypes as a function of irrigation slides. The leaf area of a plant depends on the cultivar, the number and size of the leaves and permanence in the plant, which usually increases to a maximum, then decreases due to natural senescence (CARVALHO et al., 2012).

Regarding the cultivars, there was no significant difference in the leaf area at the beginning 
of the cycle (up to 49 DAS). From this period, the CNPA G4 cultivar showed a higher average leaf area compared to the others, up to 91 DAS in season I and up to 77 DAS in season II.

The leaf area index presented a similar response to that observed for the leaf area. In season I, the maximum value was to grow CNPA G4 (3.59), followed by CNPA G3 (3.35) and CNPA G2 (2.84), obtained at 104, 85 and 88 DAS, respectively. In season II, the maximum value estimated was for CNPA G2 (2.33), followed by CNPA G4 (2.26) and CNPA G3 (1.92), obtained at 64, 76 and 60 DAS, respectively (Figure 3). The leaf area index is the relation between the leaf area and the surface of the land occupied by the plants. It is an important parameter in the analysis of growth, directly relating to the time of the growth phase, being that when reaching a maximum point loss occurs of leaves (SILVA et al., 2016). A significant difference between cultivars was observed in the leaf area index from 63 DAS in season I and 35 DAS in season II; cultivar CNPA G4 presented higher averages compared to the other cultivars, at 91 DAS in season I and at 77 DAS in season II.

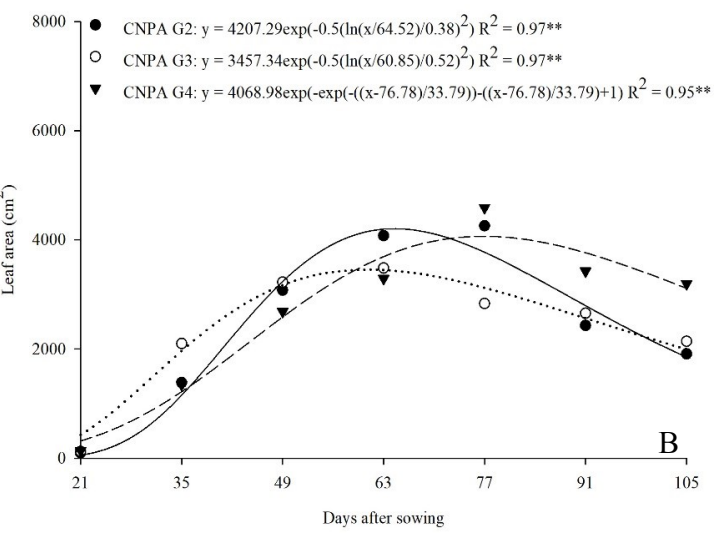

Figure 2. Leaf area in relation to harvesting season of sesame cultivars in season I (A) and season II (B).
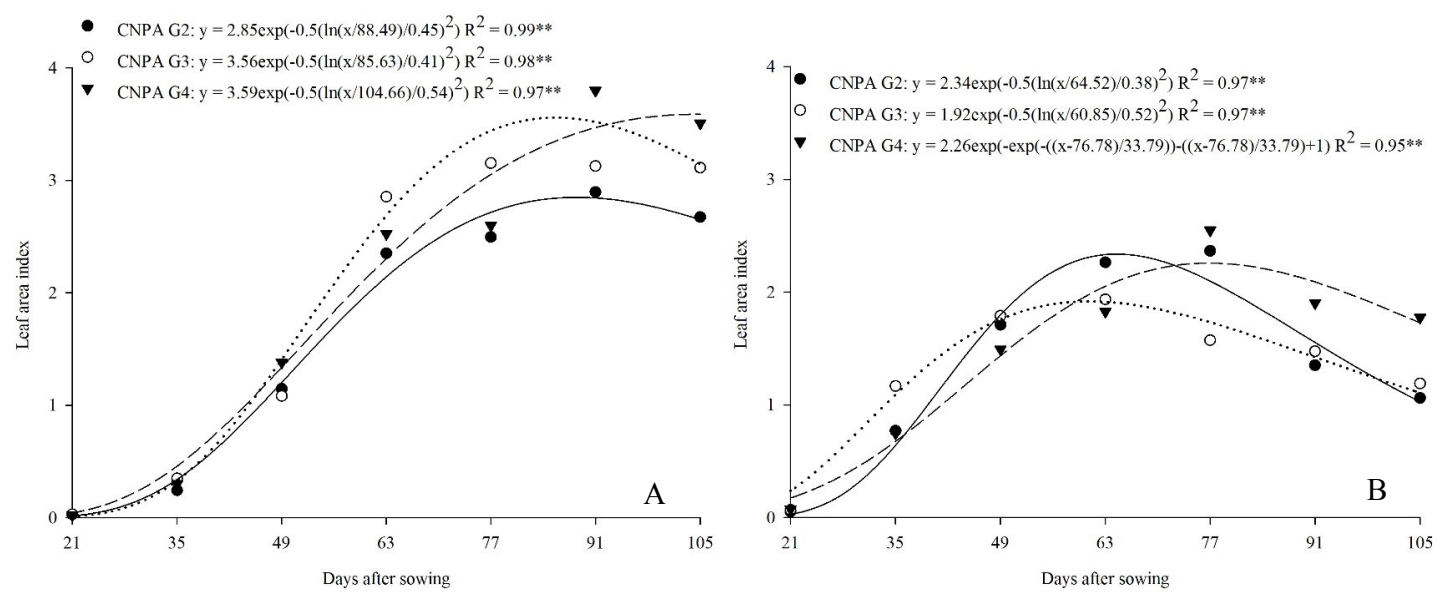

Figure 3. Leaf area index in relation to harvesting season of sesame cultivars in season I (A) and season II (B).

Evaluating the leaf area ratio in relation to harvesting season, it was verified that, regardless of the growing season, the curve showed a decreasing response maximum values at 21 DAS. In season I, the estimated maximum values were for CNPA G3 $\left(711.38 \mathrm{~cm}^{2} \mathrm{~g}^{-1}\right)$, followed by CNPA G4 $\left(428.59 \mathrm{~cm}^{2} \mathrm{~g}^{-1}\right)$ and CNPA G2 $\left(353.54 \mathrm{~cm}^{2} \mathrm{~g}^{-1}\right)$. In season II, maximum values were for CNPA G4 $\left(729.26 \mathrm{~cm}^{2} \mathrm{~g}^{-1}\right)$, followed by CNPA G2 $\left(586.24 \mathrm{~cm}^{2} \mathrm{~g}^{-1}\right)$ and CNPA G3 (483.24 $\left.\mathrm{cm}^{2} \mathrm{~g}^{-1}\right)$ (Figure 4). The leaf area ratio represents the relationship between the leaf area and the dry mass of the plant, indicating the leaf area available for photosynthesis (MORAIS; MAIA, 2013). Therefore, there is a general tendency for the leaf area ratio to fall as the plant grows, due to the decrease in useful leaf area throughout the cycle (PEIXOTO; CRUZ; PEIXOTO, 2011). Coinciding with results found by Pedó et al. (2014); Garcia et al. (2008) and Silva et al. (2007).

The absolute growth rate was initially slow, increasing up to approximately 77 DAS. In season I, the maximum growth rate was $2.37 \mathrm{~g}$ day $^{-1}$ (CNPA G2) at 69 DAS; $3.02 \mathrm{~g} \mathrm{day}^{-1}$ (CNPA G3) at 67 DAS and $4.19 \mathrm{~g} \mathrm{day}^{-1}$ (CNPA G4) at 84 DAS. In season II, maximum growth rate was $1.60 \mathrm{~g} \mathrm{day}^{-1}$ (CNPA $\mathrm{G} 2)$ at $70 \mathrm{DAS}, 1.30 \mathrm{~g} \mathrm{day}^{-1}$ (CNPA G3) at $64 \mathrm{DAS}$ and $2.79 \mathrm{~g}$ day $^{-1}$ (CNPA G4) at 105 DAS (Figure 5). The cultivar CNPA G4 obtained a maximum growth rate between 77 and 105 DAS. This characteristic shows the average growth rate throughout the observation period (BENINCASA, 1998). 

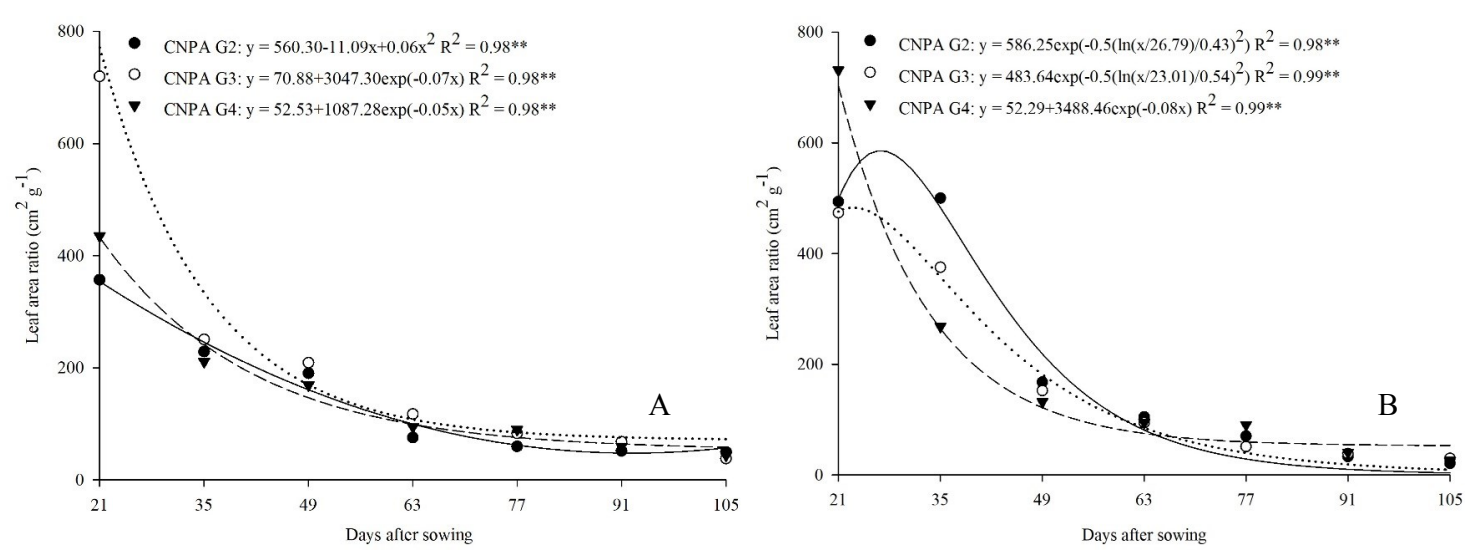

Figure 4. Leaf area ratio in relation to harvesting season of sesame cultivars in season I (A) and season II (B).
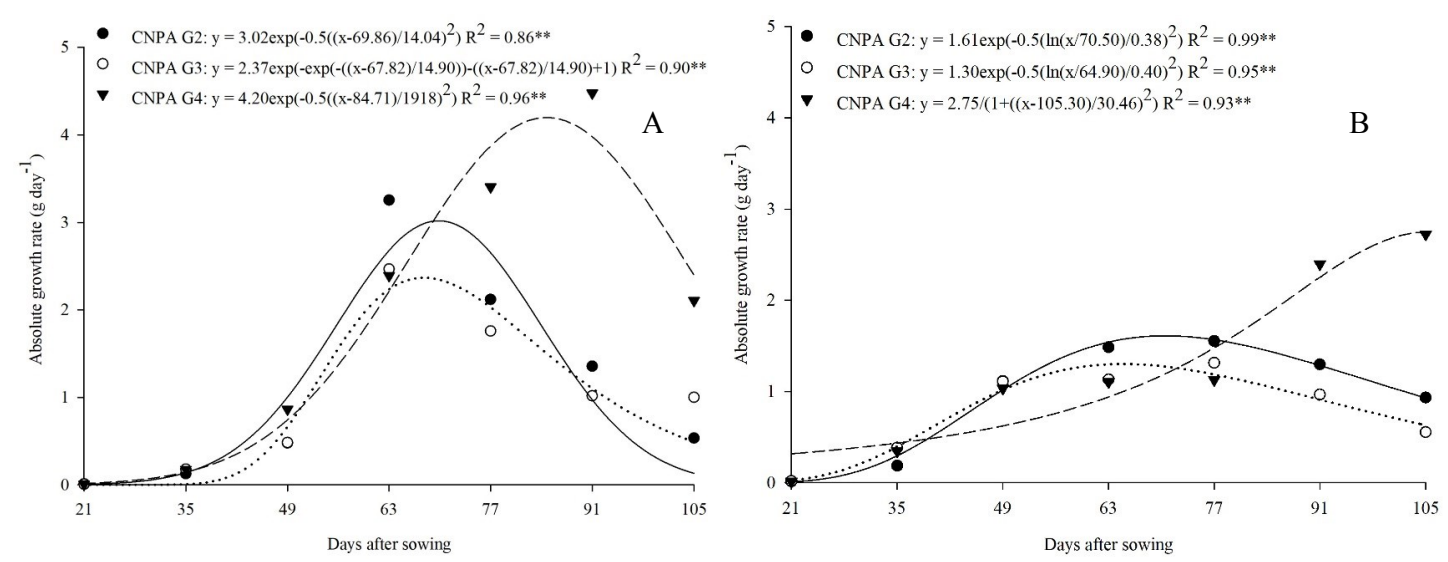

Figure 5. Absolute growth rate in relation to harvesting season of sesame cultivars in season I (A) and season II (B).

For plant growth rate'rate in relation to collection times, in season I the maximum growth rate was 0.0006 (CNPA G2) $\mathrm{g} \mathrm{cm}^{2}$ day $^{-1}$ at 86 DAS and 0.0007 (CNPA G3 and CNPA G4) $\mathrm{g} \mathrm{cm}^{2}$ day $^{-1}$ obtained at 105 DAS. In season II, values were from $0.0004 \mathrm{~g} \mathrm{~cm}^{2}$ day $^{-1}$ to 86 DAS (CNPA G2) and to 87 DAS (CNPA G3) and 0.0006 (CNPA G4) $\mathrm{g} \mathrm{cm}^{2}$ day ${ }^{-1}$ obtained at 105 DAS (Figure 6). In general, it assumed low initial values, passing through a phase of continuous growth until reaching a maximum point, being able to decrease in the final stage of the cycle, similar to the one verified by Peixoto et al. (2012).

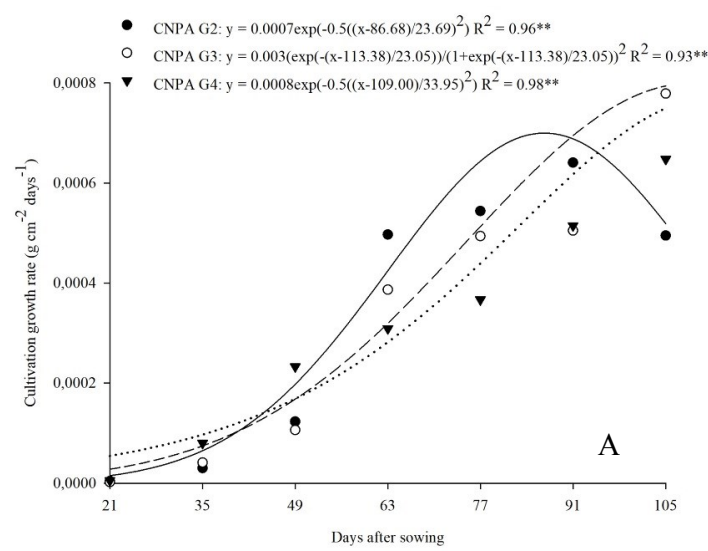

In relation to grain yield, CNPA G4 showed the highest growth in the two growing seasons, producing $1375.75 \mathrm{~kg}^{-1}$ in season I and $915.25 \mathrm{~kg} \mathrm{ha}^{-1}$ in season II (Table 1). According to Queiroga and Silva (2008), the CNPA G2, CNPA G3 and CNPA G4 cultivars, released by Embrapa, produce an average yield of 712,760 and $804 \mathrm{~kg} \mathrm{ha}^{-1}$, respectively. Pereira et al. (2010) reported a grain yield of $757 \mathrm{~kg} \mathrm{ha}^{-1}$ with CNPA G3; $842.43 \mathrm{~kg} \mathrm{ha}^{-1}$ was reported by Perin, Cruvinel and Silva (2010).

Figure 6. Cultivation growth rate in relation to harvesting season of sesame cultivars in season I (A) and season II (B). 
Table 1. Grain yield of sesame cultivars as a function of growing season.

\begin{tabular}{cccc}
\hline & & Grain yield $\left(\mathrm{kg} \mathrm{ha}^{-1}\right)$ \\
\hline \multirow{2}{*}{ Season } & & Cultivars & \\
& CNPA G2 & CNPA G3 & CNPA G4 \\
I & $867.00 \mathrm{bA}$ & $951.00 \mathrm{bA}$ & $1375.75 \mathrm{aA}$ \\
II & $875.75 \mathrm{abA}$ & $740.00 \mathrm{bB}$ & $915.25 \mathrm{aB}$ \\
\hline
\end{tabular}

Mean values followed by the same lowercase letter in the line and upper case in the column do not differ significantly from each other by Tukey's test at $5 \%$ probability.

\section{CONCLUSION}

The growth of sesame cultivars is slow at the beginning of the crop cycle, intensifying at the beginning of flowering (after 35 DAS). Among the physiological indexes studied, the CNPA G4 cultivar is more efficient in relation to growth and can vary depending on the growing season.

\section{ACKNOWLEDGEMENTS}

Special thank to the Coordenação de Aperfeiçoamento de Pessoal de Nível Superior (CAPES), for the financial support to this research.

\section{REFERENCES}

ARAÚJO, A. C. et al. Análise não destrutiva de crescimento do gergelim consorciado com feijão caupi em sistema orgânico de cultivo. Revista Brasileira de Agroecologia, Porto Alegre, v. 9, n. 1, p. 259-268, 2014.

ARRIEL, N. H. C. et al. Cultura do gergelim. 1. ed. Brasília, DF: Embrapa Informação Tecnológica, 2007. 72 p.

BENINCASA, M. M. P. Análise de crescimento de plantas: noções básicas. 2. ed. Jaboticabal, SP: FUNEP, 1998. $41 \mathrm{p}$.

BEZERRA, S. A. et al. Produção do gergelim cultivado sob condições de estresse hídrico e diferentes doses de adubação. Engenharia Ambiental, Espírito Santo do Pinhal, v. 7, n. 3, p. 156-65, 2010.

CARVALHO, D. R. et al. Comparação de métodos para estimativa da área foliar do Myrciaria tenella $\mathrm{O}$. Berg. Agropecuária Científica no Semi-Árido, Campina Grande, v. 8, n. 4, p. 01-06, 2012.

CAVALCANTI, F. J. A. et al. Recomendações de adubação para o estado de Pernambuco: $2^{\text {a }}$ aproximação. 3. ed. Recife, PE: IPA, 2008. 212 p.
EMPRESA BRASILEIRA DE PESQUISA AGROPECUÁRIA - EMBRAPA. Sistema brasileiro de classificação de solos. 3 . ed. Brasília, DF: Embrapa Informação Tecnológica, 2013. 353 p.

FOOD AND AGRICULTURE ORGANIZATION OF THE UNITED NATIONS - FAO. Production quantities of Sesame seed by country. Disponível em: $\quad<$ http://faostat3.fao.org/browse/Q/QC/E> Acesso em: 03 jul. 2016.

FERRARI, T. B. et al. Efeito de reguladores vegetais nos índices da análise de crescimento de plântulas de maracujazeiro-doce (Passiflora alata Curtis) Biotemas, Florianópolis, v. 21, n. 3, p. 45-51, 2008.

FERREIRA, D. F. Sisvar: a computer statistical analysis system. Ciência e Agrotecnologia, Lavras, v. 35, n. 6, p. 1039-1042, 2011.

GARCIA, A. et al. Análise de crescimento de uma cultura de milho submetida a diferentes regimes hídricos. Nucleus, Ituverava, v. 5, n. 1, p. 239-251, 2008.

GRILO JUNIOR, J. A. S.; AZEVEDO, P. V. Crescimento, desenvolvimento e produtividade do gergelim BRS seda na agrovila de Canudos, em Ceará Mirim (RN). HOLOS, Natal, v. 2, n. 29, p. 19 $-33,2013$.

HARUNA, I. M. et al. Contributions of some growth characters to seed yield of sesame (Sesamum indicum L.). Journal of Food and Agriculture Science, Londres, v. 2, n. 1, p. 9-14, 2012.

LAURETIN, H.; BENÍTEZ, T. Inheritance of seed coat color in sesame. Pesquisa Agropecuária Brasileira, Brasília, v. 49, n. 4, p. 290-295, 2014.

LIMA, F. A. et al. Irrigação da cultura do gergelim em solo com biofertilizante bovino. Revista Brasileira de Agricultura Irrigada, Fortaleza, v. 7, n. 2, p. 102-111, 2013.

LUCENA, R. R. M. et al. Acúmulo de massa seca e nutrientes pelo tomateiro 'SM-16' cultivado em solo com diferentes coberturas. Horticultura Brasileira, 
Brasília, v. 31, n. 3, p. 401-409, 2013.

MORAIS, E. R. C.; MAIA, C. E. Crescimento da parte aérea e raiz do meloeiro adubado com fertilizante orgânico. Revista Ciência Agronômica, Fortaleza, v. 44, n. 3, p. 505-511, 2013.

MORRIS, J. B. Characterization of sesame (Sesamum indicum L.) germplasm regenerated in Georgia, USA. Genetic Resources and Crop Evolution, Sousse, v. 56, n. 7, p. 925-936, 2009.

PEDÓ, T. et al. Análise de crescimento de plantas de rabanete submetidas a doses de adubação nitrogenada. Bioscience Journal, Uberlândia, v. 30, n. 1, p. 1-7, 2014

PEIXOTO, C. P.; CRUZ, T. V.; PEIXOTO, M. F. S. P. Análise quantitativa do crescimento de plantas: Conceitos e Prática. Enciclopédia Biosfera - Centro Científico Conhecer, Goiânia, v. 7, n. 13, p. 51-76, 2011.

PEIXOTO, C. P. et al. Índices fisiológicos de soja hortaliça em duas épocas de semeadura no Recôncavo Sul Baiano. Scientia Agraria Paranaensis, Marechal Cândido Rondon, v. 11, n. 3, p. 56-67, 2012.

PEREIRA, M. R. R. et al. Análise de crescimento em clones de eucalipto submetidos a estresse hídrico. Irriga, Botucatu, v. 15, n. 1, p. 98-110, 2010.

PERIN, A.; CRUVINEL, J. D.; SILVA, W. J. Desempenho do gergelim em função da adubação NPK e do nível de fertilidade do solo. Acta Scientiarum Agronomy, Maringá, v. 32, n. 1, p. 9398, 2010.

PHAM, T. D. et al. Morphological evaluation of sesame (Sesamum indicum L.) varieties from different origins. Australian Journal Of Crop Science, Brisbane, v. 4, n. 7, p. 498-504, 2010.

QUEIROGA, V. P.; SILVA, O. R. R. F. Tecnologias Utilizadas no Cultivo do Gergelim Mecanizado. 1. ed. Campina Grande, PB: EMBRAPA-CNPA, 2008. $142 \mathrm{p}$.

SILVA, J. C. A. et al. Crescimento e produção de genótipos de gergelim em função de lâminas de irrigação. Revista Brasileira de Engenharia Agrícola e Ambiental, Campina Grande, v. 18, n. 4, p. 408-416, 2014

SILVA, L. C. et al. Um método simples para se estimar área foliar de plantas de gergelim (Sesamum indicum L.). Revista Brasileira de Oleaginosa e
Fibrosa, Campina Grande, v. 6, n. 1, p. 491-495, 2002 .

SILVA, M. A. V. et al. Influência das condições microclimáticas no crescimento do milho BR 106, cultivado sob sementeira direta. Revista de Ciências Agrárias, Lisboa, v. 39, n. 3, p. 383-394, 2016.

SILVA, R. N. et al. Análise de crescimento de plantas de Hordeum vulgare $\mathrm{L}$. submetidas a estresse salino. Revista Brasileira Agrociência, Pelotas, v. 13, n. 4, p. 455-463, 2007. 